\title{
Acase-control study related to vitamin and mineral intake in female adolescents with iron deficiency anemia
}

DOI: dx.doi.org/10.22435/hsji.v11i1.3066

Dwi Rahayu ${ }^{1,3}$, Dono Indarto ${ }^{2,3}$

${ }^{1}$ Department of Nutrition, Faculty of Medicine, Universitas Sebelas Maret, Surakarta, Indonesia

${ }^{2}$ Department of Physiology, Faculty of Medicine, Universitas Sebelas Maret, Surakarta, Indonesia

${ }^{3}$ Department of Biomedic, Faculty of Medicine, Universitas Sebelas Maret, Surakarta, Indonesia

Corresponding author: Dwi Rahayu

Email: dwi.rahayu.dr@staff.uns.ac.id

Received: December 17, 2019; Revised: March 3, 2020; Accepted: May 28, 2020.

\begin{abstract}
Abstrak
Latar belakang: Anemia defisensi besi (ADB) merupakan salah satu masalah nutrisi pada remaja putri di seluruh dunia. Penyerapan zat besi di usus halus dipengaruhi oleh adanya vitamin $C$, kalsium, dan zink pada makanan. Penelitian ini bertujuan untuk mengetahui hubungan pola konsumsi vitamin A, vitamin $C$, kalsium dan zink terhadap kejadian ADB pada remaja putri.

Metode: Penelitian ini merupakan penelitian case control yang melibatkan 60 remaja putri dengan $A D B$ dan 58 remaja putri tanpa ADB. Diagnosis ADB berdasarkan kadar Hb dan indeks eritrosit, dan semikuantitatif FFQ digunakan untuk menentukan asupan vitamin dan mineral. Semua data dianalisis menggunakan test chi square dan tes regresi logistik ganda dengan $p<0.05$.

Hasil: Semua subjek penelitian mempunyai asupan vitamin A dan C harian yang cukup tetapi asupan kalsium dan zinknya tergolong kurang (dalam mg). Namun, mereka semua memiliki frekuensi harian yang berbeda dalam mengkonsumsi mikronutrien tersebut. Remaja putri dengan asupan vitamin A yang jarang $(O R=2.67$; $C 195 \%=1.10-6.50 ; p=0.03)$ dan asupan kalsium yang sering $(O R=2.27 ; C 195 \%=0.85-6.03 ; p=0.10)$ lebih berisiko terkena $A D B$ dibandingkan dengan remaja putri dengan asupan vitamin A yang sering dan asupan kalsium yang jarang. Akan tetapi hanya asupan vitamin A yang memiliki efek signifikan secara statistik.
\end{abstract}

Kesimpulan: Hasil penelitian ini menunjukkan bahwa tingginya risiko ADB pada remaja putri berkaitan dengan asupan vitamin A yang jarang. (Health Science Journal of Indonesia 2020;11(1):52-6)

Kata kunci: anemia defisiensi besi, asupan mikronutrien, remaja putri

\begin{abstract}
Background: Iron deficiency anemia (IDA) is a nutritional problem that occurs in female adolescents around the world. Iron absorption in the small intestine is influenced by the presence of vitamin $\mathrm{C}$, calcium, and zinc in ingested foods. This study aimed to investigate the relationship of vitamin A, vitamin $\mathrm{C}$, calcium, and zinc intake with IDA in female adolescents.
\end{abstract}

Methods: This case-control study was conducted in 60 anemic and 58 normal female adolescents. IDA diagnosis was determined using $\mathrm{Hb}$ levels and erythrocyte indexes and the semiquantitative food frequency questionnaire was used to determine vitamin and mineral intake. All collected data were analyzed using chisquare and multiple logistic regression tests with $\mathrm{p}<0.05$.

Results: All groups had an adequate intake of vitamin $\mathrm{A}$ and $\mathrm{C}$ but they had inadequate intake of calcium and zinc (in $\mathrm{mg}$ ). However, they all had different frequencies in consuming those micronutrients. Rare intake of vitamin $\mathrm{A}(\mathrm{OR}=2.67$; $\mathrm{CI} 95 \%=1.10-6.50 ; \mathrm{p}=0.03)$ and frequent intake of calcium $(\mathrm{OR}=2.27 ; \mathrm{CI} 95 \%=0.85$ $6.03 ; \mathrm{p}=0.10$ ) increased IDA, compared with frequent intake of vitamin A and rare intake of calcium but only vitamin A intake had a significant effect.

Conclusion: Our findings suggest that a higher risk of IDA in female adolescents is related to a rare intake of vitamin A. (Health Science Journal of Indonesia 2020;11(1):52-6)

Keywords: Iron deficiency anemia; micronutrient intake; female adolescents 
Anemia is a major public health problem that around 1.62 billion people worldwide and iron deficiency is the most common cause of anemia. ${ }^{1}$ Meanwhile, the prevalence of anemia in Indonesia is $48 \%$ in pregnant women $^{2}, 18 \%$ in female adolescents, and $28 \%$ in children. $^{3}$ Therefore, prolonged iron deficiency anemia (IDA) in the vulnerable age-groups will increase maternal morbidity and mortality rates $^{4}$, lower adolescents learning achievement ${ }^{5,6}$, and disturb children cognitive and motor development. ${ }^{7}$

Multifactor contribute to IDA pathogenesis such as nutrition, infection, and genetics. The most common etiology of anemia in developing countries is the nutrition factor. ${ }^{8}$ Inadequate intake of vitamins such as vitamin A, B12, C and folic acid is also found in people with anemia. A number of studies reported that calcium and zinc can decrease iron absorption by inhibition of Iron-DMT1 binding complexes in the small intestine. ${ }^{9,10}$ Based on the background above, this study aimed to investigate the relationship between vitamin $\mathrm{A}$, vitamin $\mathrm{C}$, calcium and zinc intake and IDA in female adolescents.

\section{METHODS}

This study was an analytic study with a case-control approach, which conducted from June to August 2017. Research subjects of this study were 60 adolescent females with IDA, who had hemoglobin level of $<12 \mathrm{~g} / \mathrm{dL}$, mean corpuscular volume (MCV) of $<80 \mathrm{fL}$ and mean corpuscular hemoglobin $(\mathrm{MCH})$ of $<30 \mathrm{pg} / \mathrm{cell}$ as the case group while 58 female adolescents with $\mathrm{Hb} \geq 12 \mathrm{~g} / \mathrm{dL}, \mathrm{MCV} \geq 80 \mathrm{fl}$, and $\mathrm{MCH} \geq 30 \mathrm{pg} / \mathrm{cell}$ as the control group. ${ }^{11}$ The selected subjects aged 15-19 years came from 4 senior high schools at Sukoharjo regency. From anamnesis, research subjects were excluded from this study if were menstruating and had chronic diseases such as pulmonary tuberculosis, blood disorders, and metabolic diseases. All research subjects agreed to participate in this study by signing the informed consent.

Venous blood was taken from lower arms of research subjects and $\mathrm{Hb}$ level was measured using the standard method of hemoglobin measurement. ${ }^{12}$ The semiquantitative food frequency questionnaire (SFFQ) was used to determine vitamin A, vitamin $\mathrm{C}$, calcium, and zinc intake. Calculated values of nutrient intake were compared with nutrient intake values from the Indonesian recommended dietary allowance (RDA). ${ }^{13}$ The consumption frequency of micronutrients used the average frequency of daily intake in both groups All collected data were then analyzed using chi-square and multiple logistic regression tests with $\mathrm{p}<0.05$. This research protocol was approved by the Human Research Ethics Committee at the Public Hospital Moewardi, Surakarta number 585/VI/HREC/2017.

\section{RESULTS}

Table 1 showed that there were no mean differences between case and control groups in terms of age, menarche, and menstrual duration except BMI. A lower mean of menarche age, menstrual duration, and BMI was observed in the case group, compared with the control group but only the mean BMI reached a statistical significance $(\mathrm{p}=0.005)$. This study showed that the case groups had a higher risk of IDA compared to the control group, eventhough both groups had a normal BMI. This condition happened because subject who had lower BMI probably had a low intake of nutrient. In contrast, the case group had a higher mean age than the control group.

Table 1. Basic characteristics of female adolescents with or without IDA.

\begin{tabular}{lccc}
\hline & Case $(\mathrm{n}=60)$ & Control $(\mathrm{n}=58)$ & $\mathrm{p}$ \\
\hline Age (y.o.) & $16.38 \pm 0.82$ & $16.29 \pm 0.72$ & $0.374^{*}$ \\
Menarche (years old) & $12.76 \pm 1.30$ & $12.86 \pm 1.43$ & $0.755^{*}$ \\
Menstrual duration & $6.46 \pm 0.99$ & $6.67 \pm 1.06$ & $0.151^{*}$ \\
(days) & & & \\
BMI $\left(\mathrm{kg} / \mathrm{m}^{2}\right)$ & $19.74 \pm 2.34$ & $21.30 \pm 3.41$ & 0.005 \\
\hline
\end{tabular}

Data presented as mean \pm SD and *used the Mann-Whitney test

We determined energy and macronutrients intakes in both groups using the SFFQ and converted it into daily intake using the Nutrisurvey software. As presented in Table 2, the mean daily intake of energy, iron, calcium and zinc in both groups was below the RDA, while the case group had a lower intake of energy, vitamin $\mathrm{C}$ and zinc compared to those intakes in the control group. Additionally, excessive intake of vitamin A and $\mathrm{C}$ was found in both groups. Overall the difference mean of daily intake in both groups was not statistically significant.

The chi-square and multiple logistic regression tests were used to analyze the relationship between vitamin and mineral dietary pattern and the risk of IDA. According to Table 3, vitamin A was the only nutrient that had a significant relationship to the risk of IDA in which decline the risk of IDA. While, the dietary pattern of vitamin $\mathrm{C}$ and calcium was positively related to the risk of IDA and the dietary pattern of zinc decreased the risk of IDA, although those data were not statistically significant. 
Table 2. Energy and micronutrients intake in female adolescents with or without IDA.

\begin{tabular}{lcllc}
\hline Nutrient intake & RDA & \multicolumn{1}{c}{ Case (n=60) } & Control (n=58) & P \\
\hline Energy (kcal) & 2125 & $1665.31 \pm 594.12(78.35)$ & $1947.02 \pm 1687.17(91.62)$ & 0.22 \\
Protein (gr) & 59 & $75.59 \pm 34.21(127.11)$ & $75.59 \pm 31.54(127.11)$ & 0.99 \\
Iron (m) & 26 & $21.42 \pm 16.90(82.34)$ & $20.39 \pm 13.50(78.42)$ & 0.83 \\
Vitamin A (mcg) & 600 & $1981.50 \pm 1646.47(330.25)$ & $1868.26 \pm 1583.88(311.37)$ & $0.59^{*}$ \\
Vitamin C (mg) & 75 & $154.26 \pm 139.97(205.68)$ & $175.26 \pm 119.18(233.68)$ & $0.09^{*}$ \\
Calcium (mg) & 1200 & $755.80 \pm 535.99(62.98)$ & $747.57 \pm 441.24(62.29)$ & $0.61^{*}$ \\
Zinc (mg) & 14 & $8.54 \pm 3.43(61.00)$ & $8.71 \pm 3.42(62.21)$ & 0.78 \\
\hline
\end{tabular}

Data presented as mean \pm SD and *used the Mann-Whitney test

Table 3. The relationship between dietary pattern of vitamin A, vitamin C, calcium and zinc in female adolescents with or without IDA.

\begin{tabular}{|c|c|c|c|c|c|}
\hline Food intake & $\begin{array}{l}\text { Case } \\
\mathrm{n}(\%)\end{array}$ & $\begin{array}{c}\text { Control } \\
\mathrm{n}(\%)\end{array}$ & OR & $\begin{array}{c}\text { C.I 95\% } \\
\text { (min-max) }\end{array}$ & $\mathrm{P}$ \\
\hline Vitamin A (times/day) & & & 2.28 & $1.09-4.77$ & $0.04 *$ \\
\hline$-\quad<\operatorname{mean}(3.44)$ & $36(61)$ & $23(39)$ & & & \\
\hline - $\quad \geq$ mean & $24(40.7)$ & $35(59.3)$ & & & \\
\hline Vitamin C (times / day) & & & 1.40 & $0.68-2.90$ & 0.45 \\
\hline$-\quad<\operatorname{mean}(3.30)$ & $32(55.2)$ & $26(44.8)$ & & & \\
\hline$-\quad \geq$ mean & $28(46.7)$ & $32(53.3)$ & & & \\
\hline Calcium (times / day) & & & 1.22 & $0.59-2.52$ & 0.71 \\
\hline$-\quad<\operatorname{mean}(5.00)$ & $28(48.3)$ & $30(51.7)$ & & & \\
\hline$-\quad \geq$ mean & $32(53.3)$ & $28(46.7)$ & & & \\
\hline Zinc (times / day) & & & 0.76 & $0.37-1.57$ & 0.58 \\
\hline$-\quad<$ mean $(2.83)$ & $32(54.2)$ & $27(45.8)$ & & & \\
\hline$-\quad \geq$ mean & $28(47.4)$ & $31(52.6)$ & & & \\
\hline
\end{tabular}

Chi-square test

Table 4. Multiple logistic regressions of dietary pattern of vitamin A, vitamin C, calcium and zinc with IDA.

\begin{tabular}{lccc}
\hline & OR & C.I 95\% (min-max) & $\mathrm{p}$ \\
\hline Constant & 0.51 & & 0.15 \\
Rare intake of vitamin A & 2.67 & $1.10-6.50$ & 0.03 \\
Rare intake of vitamin C & 1.00 & $0.41-2.41$ & 0.99 \\
Frequent intake of calcium & 2.27 & $0.85-6.03$ & 0.10 \\
Frequent intake of zinc & 0.64 & $0.25-6.03$ & 0.36 \\
\hline Nagelkerke R Square & & $8.5 \%$ &
\end{tabular}

Table 4 showed a statistical analysis of all variables that influenced hemoglobin synthesis. Stronger associations were observed in a rare intake of vitamin $\mathrm{A}$ and a frequent intake of calcium but only the dietary pattern of vitamin A reached significantly. The protective effect of frequent intake of zinc was as same as the result of a bivariate analysis and it was not statistically significant.

\section{DISCUSSION}

From our results about nutrients daily intake (in $\mathrm{mg}$ ) seems not to contribute to IDA pathogenesis in female adolescents. Daily intake of protein, iron, vitamin A, vitamin $\mathrm{C}$, and zinc in female adolescents with IDA was similar to female adolescents without IDA. It is more likely that other factors are involved in the IDA pathogenesis. For example, hookworm infection is the most common cause of IDA in tropical countries like Indonesia. ${ }^{14}$ This happens because the worm is associated with chronically mild bleeding, which leads to iron deficiency. ${ }^{15}$

Based on the daily pattern, our findings suggested that female adolescents who have infrequent intakes of vitamin A and frequent intakes of calcium are susceptible to suffer IDA. This study, however, only vitamin A intake that had a significant contribution in 
decreasing in IDA. In normal conditions, vitamin A can increase blood iron concentration through direct and indirect actions. Vitamin A deficiency might inhibit the expression of ferroportin and mobilization of iron from the liver storage by direct pathway. This pathway results in a low iron concentration in the blood circulation. Meanwhile, the indirect effect of vitamin A deficiency affects the immune system by reduction of antibody production, lymphocyte proliferation, and epithelial integrity, leading to an increase of iron usage. ${ }^{16}$ In addition, frequent intake of calcium will increase iron deficiency due to competitive inhibition in the active site of the DMT1 protein. ${ }^{9}$ Supporting this study, a study involving 696 children in Brazil showed IDA were associated with low levels of serum retinol (low levels of retinol lead to vitamin A deficiency). ${ }^{16}$ Moreover, several systematic reviews showed that the supplementation of vitamin A in children, adolescence, and pregnant women had a positive effect on hemoglobin and other parameters of iron, such as ferritin. ${ }^{17,18}$ Otherwise, research in Greece, which involved more than 1000 female adolescents, explained that iron depletion was associated with high calcium intake. ${ }^{19}$ However, quantitative measurements of food intake by SFFQ should be combined with another method like 24hour food recall. Furthermore, a cohort study is required to confirm this case-control study in order to find out the specific roles of vitamin A and calcium in IDA pathogenesis.

In conclusion, the daily pattern of rare vitamin $\mathrm{A}$ intake increases the risk of IDA in female adolescents in Sukoharjo regency. However, these results cannot be generalized because we only used the daily pattern of vitamin and mineral intake, and we did not combine with other methods to obtain data of daily intake of vitamins and minerals.

\section{Acknowledgments}

A part of data generated from this study got a research grant from Risbin IPTEKDOK 2015 by the Indonesian Health Ministry. We declared that there was no conflict of interest in this study.

\section{REFERENCES}

1. de Benoist B, Mclean E, Egli I, Cogswell M. Worldwide prevalece of anaemia 1993-2005: WHO global database on anemia. Geneva:WHO;2008.

2. National Institute of Health Research and Development. [Final report of national basic health research 2018]. Jakarta: The Institute; 2018. Indonesian.
3. National Institute of Health Research and Development. [Final report of national basic health research 2013]. Jakarta: The Institute; 2013. Indonesian.

4. Stoltzfus RJ, Dreyfuss ML. Guidelines for the use of iron supplements to prevent and treat iron deficiency anemia. Washington DC: International Life Sciences Institute Press;2008.

5. More S, Shivkumar VB, Gangane N, Shende S. Effects of iron deficiency on cognitive function in school going adolescent females in rural area of Central India. Anemia. 2013:1-6.

6. Soleimani N. Relationship between anaemia, caused from the iron deficiency, and academic achievement among third grade high school female students. Procedia - Social and Behavioral Sciences. 2011;29:1877-84.

7. World Health Organization. Global nutrition targets 2025: anaemia policy brief. Geneva:WHO;2014.

8. Johnson-Wimbley TD, Graham DY. Diagnosis and management of iron deficiency anemia in the 21st century. Therap Adv Gastroenterol. 2011; 4:177-84.

9. Iyengar V, Pullakhandam R, Nair KM. Coordinate expression and localization of iron and zinc transporters explain iron-zinc interactions during uptake in Caco-2 Cells: implications for iron uptake at the Enterocyte. J Nutr Biochem. 2012; 23:1146-54.

10. Hurrell R, Egli I. Iron bioavailability and dietary reference values. Am J Clin Nutr. 2010; 91:1461S-7S.

11. Regulation of Ministry of Health Republic Indonesia. Peraturan Menteri Kesehatan Republik Indonesia Nomor 5 Tahun 2014 tentang Panduan Praktik Klinis bagi Dokter di Fasilitas Pelayanan Kesehatan Primer. Jakarta: The Institute; 2014. Indonesian.

12. Srivastava T, Negandhi H, Neogi SB, Sharma J, Saxena R. Methods for hemoglobin estimation: a review of "What Works". J Hematol Transfus. 2014;2:1028.

13. Regulation of Ministry of Health Republic Indonesia. Peraturan Menteri Kesehatan Republik Indonesia Nomor 28 Tahun 2019 tentang Angka Kecukupan Gizi yang dianjurkan bagi bangsa Indonesia. Jakarta: The Institute; 2019. Indonesian.

14. Rodríguez-Guardado A, Pozo E, Fernandez-García R, Amo-Fernandez J, Nozal-Gancedo T. Hookworm disease as a cause of iron deficiency anemia in the prison population. Rev Esp Sanid Penit. 2013;15:63-5.

15. Peixoto A, Goncalves R, Silva M, Gaspar R, Silva R, Portugal R et al. Eosinophilic ileocolitis due to Enterobius vermicularis infection: a rare cause of anemia. International Journal of Colorectal Disease. 2015;31:743

16. Saraiva BCA, Soares MCC, dos Santos L, Pereira SCL, Horta PM. Iron deficiency and anemia are associated with low retinol levels in children aged 1 to 5 years. Jornal de Pediatria. 2014;90:6

17. Michelazzo FB, Oliveira JM, Stefanello J, Luzia LA, Rondó PHC. Review the influence of vitamin A supplementation on iron status. Nutrients. 2013;5:4399-413 
18. da Cunha MSB, Hankins NAC, Arruda SF. Effect of vitamin A supplementation on iron status in humans: a systematic review and meta-analysis. Crit Rev Food Sci Nutr. 2019;59:1767-81
19. Moschonis G, Papandreou D, Mavrogianni C, Giannopoulou A, Damianidi L, Malindretos P. Association of iron depletion with menstruation and dietary intake indices in pubertal girls: the healthy growth study. BioMed Research International. 2013:1-8 